\title{
Elementary English teaching: a door to the American and native culture
}

\author{
M. Ed. Karol Cubero Vázquez
}

Last year a friend of mine was dating an American girl. During their passionate relationship, he tells his American girlfriend, "l'll give you a ring tomorrow.» Trying to say that he would call her by phone, but she understood that he had offered her a jewel. Unfortunately, the relationship didn't survive due to this misunderstanding and my friend got a broken heart.

In view of this, it is reasonable to assert that cultural awareness plays an essential role while communicating with other people culturally different. We can get the right word, but the wrong concept.

We live surrounded by culture in everything we do. Everything we say and the ways we use to express our feelings and thoughts carry out insights of cultural details. There is no way in which language can be considered apart from culture.

In the field of foreign language teaching, one issue that occasionally emerges as a topic of discussion is the relationship between teaching the language itself and the culture of the language. 
Language teaching is a profession in which a lot of factors are needed in order to do our job successfully. One of those aspects is definitely the teaching of culture.

Many language teaching experts agree on the great importance of teaching culture and language simultaneously because it helps in many ways to the development of communicative skills in language learners.

Recent researches on this issue have shown that language learners not exposed to cultural elements of the target community find it very hard to communicate clear messages and meaning to native speakers.

Unfortunately, that is happening with our elementary school students, where the foreign language teaching methodology for public elementary schools in our country does not consider such an important issue, part of the curriculum.

As an English teacher, in the elementary classroom I have observed that this issue is far from becoming a reality, cultural elements of cultures in which English is spoken are not being brought to the classroom.

Costa Rican English teachers and authorities in the elementary classroom should be aware that teaching a foreign language is not merely about teaching the students how to communicate, but also to expose them to cultural elements of both cultures (target and native) in order to facilitate the understanding of the language itself.

So, the relationship between language and culture is a matter that seems to have no significance, due to teachers are not aware of the importance of teaching the language parallel to the teaching of culture.

However, the major reason for not teaching the target culture lies in the syllabus for teaching English in the elementary classroom which does not give so much support to the study of language and culture interrelated. 
As to my limited experience at the university level, the situation seems not so much different in comparison to what happens in the elementary classroom.

In English teaching careers most of the courses are based on teaching the language in isolation from the target culture waiting for the students to master the language. Later, the students are asked to take some courses to study some cultural elements of the American culture in completely isolation.

This situation needs to be evaluated in order to redirect the teaching of English in our public elementary classrooms. Children can absorb and acquire better the language if we teach them using the correct methodologies and taking in to account important issues such as the one in question here.

From the integration of culture and language we can get many benefits and great advantages while teaching English to our children in public elementary schools.

We can not go on thinking about teaching English without giving at least some cultural details of one community in which the language is spoken; teaching a language must be teaching culture.

It is really important to let English teachers know that we can teach our young learners a lot of great things from one of the cultures of the language they are learning and their own.

In this case I propose the study of English along the American and native culture in public elementary schools.

Therefore, the aim of this paper is to point out the importance and benefits of teaching English parallel to the teaching of the American and native culture in public elementary schools, as well as to present different techniques and activities for teaching children from ages of 8 to 12 years old. 
I will also present some considerations from teaching my students in Bernardo Gutiérrez elementary school cultural details about American culture at the time we reinforce our Costa Rican culture through different activities and material with the objective of providing a total emerge in English classes.

(For the purpose of this paper I would use target culture referring to the promotion of teaching American culture in English classes).

I have been teaching English for five years in a public elementary school, thanks to the master program that I am taking I could understand better all the essential steps and methodology providing to my students better opportunities for language acquisition to take place.

Specifically, the integration between culture and language, I found this information really interesting. Additionally, I increased my interest on this issue when I realized that some of my English colleagues share the same feeling of frustration teaching every year the same English topics and units.

That was the moment when I decided to give it a try and change the English teaching routine. So, I started to bring to my English classes culture information and details about the American culture to see how my students respond.

After the first class I was amazed on how well my students respond to the new content. Even the little kids showed curiosity on how American people live.

They were actively involved in the activities showing appreciation for the target culture as well as their own.

Without no doubt, teaching young students the culture of the United States will make them discover a new way of life at the time they can reinforce our Costa Rican culture. Fortunately, I am getting good results from this integration. 
However, it is kind of difficult to implement this idea in different public elementary schools due to there are no guidelines for teaching the American culture in the elementary classroom neither the program provided by the MEP gives an orientation to the study of the target culture in connection with the teaching of English.

Another reason is that teachers are not being well instructed in Universities about the importance of teaching culture and language simultaneously.

This scenario is unfavorable to the teaching of English in our elementary schools because it takes away great benefits and opportunities for our students to get better in English.

According to the program provided by the MEP, the teaching of English in public elementary schools is based on linguistic objectives; pursuiting the development of language skills listening, reading, speaking, and writing.

If we study carefully the program for teaching English in I and II cycles provided by the MEP we can find that there are no culture objectives or units, which means, as I said before, that culture is not being considered as an integral part in the teaching of English as a foreign language in our public elementary schools.

This situation is really sad. Not even our authorities believe in the importance and contributions of integrating culture and language in the acquisition of a foreign language.

In order to communicate effectively with native speakers we should handle some culture information. Specially, in our country influenced tremendously from the United States.

Likewise, for students, language study seems senseless if they know nothing about the people who speak the target language or the country in which the target language is spoken. 
No information about the people who speak that language is like presenting them fictive people living who knows where; students need concrete facts, real life situations. If they knew they would be dealing with genuine people. Then they would respond positively to the new material.

Acquiring a new language means a lot more than the manipulation of syntax and lexicon. Language learners need to know appropriate ways to address people, express gratitude, make requests, agree or disagree with someone and other important cultural elements.

In order to do so we have to remember that foreign language learning is comprised of several components including, grammatical competence, communicative competence, language proficiency and cultural competence: understood as the knowledge of customs, beliefs, and systems of meaning of another country.

Undoubtedly, the last component has been left aside; English teachers have been focusing their teaching based on just one or two components forgetting that each one plays an essential role during the acquisition of a language.

In reality, what most teachers and authorities seem to lose sight of is the fact that knowledge of the grammatical system of a language (grammatical competence) has to be complemented by understanding the culture specific meanings that portrays implicit messages (cultural competence).

Language as we know is a social institution, a body of words and system for its use between people of the same community. Now let's analyze this concept, if language refers to the body of words only spoken by the people in their own community.

Clearly, language everyday is tinged with cultural bits it has no independent existence, it exist only on the mouths, 
ears, and eyes of its users. That is why we as teachers have to provide to the students information about the way some American people act, behave, and live.

Ignoring this fact will definitely apart the students from: understanding the context in which the target language is being used, getting the idea of messages about political, social, religious, or economic system or talking appropriately.

It has been emphasized so far that without the study of culture, the teaching of English is inaccurate and incomplete. Therefore, teaching at least the American culture as an integral part in English teaching should become an important goal in most elementary classrooms.

Definitely, a familiarization with the culture of the United States should be present every day while we teach English in our elementary schools.In that way the study of English will be easier, the classes will become more enjoyable and attractive not only for students but for teachers.

I am sure that as I experienced, English teachers will find themselves improving their profession, becoming foreign culture teachers with the ability of teaching and analyzing with the students both home and target cultures.

By all means, the integration of language and culture provides a series of benefits during English acquisition.

At this point I would like to point out the advantages that we can get from integrating American and native culture with the teaching of English.

Studying English through American culture allows the students to understand behaviors from the perspective of members of that society; they can develop empathy toward the country and its people.

Specially now, that globalization forces us to speak English effectively in order to compete in the global community. We would not be able to send clear messages if we lack target culture knowledge. 
Culture details allow students to open the doors on the target and native culture, giving them the opportunity to see a new world, learning to make comparisons and contracts.

Besides, the teaching of foreign language and culture locate students in front of the whole picture that represents an unknown community. Students can learn common attitudes, beliefs and values that are reflected in the way members of a group use the language.

In that sense, culture classes enable the students to see themselves from a different point of view humanizing and evaluating both cultures.

Another advantage is communication; instills in students an intellectual and emotional appreciation of the American culture and the foreign language they are being exposed to. They can express feelings, ideas, and opinions or even ask questions in relation to both cultures.

There is, without no doubt, a great increase in students' level of interest, curiosity and motivation toward the learning of English.

Nevertheless, not all is going to be easy or positive while teaching young learners culture information. In some cases, depending on the groups' characteristics, we may face uncomfortable situations in relation to issues like discrimination, prejudice, superiority, racism, and other negative attitudes.

The key is to let the students know that different does not mean deficient; on the contrary, there are many great, valuable, interesting things from other cultures that can enrich our lives.

This explanation will also help the students to respect and accept other students culturally different in the classroom, school, and community.

The issue of discrimination affects many elementary schools around the country because we deal with 
multicultural classrooms. However, we can work some extra time on discussing values and contributions we get from other people culturally different.

I have further stated the importance, advantages and contributions of integrating the teaching of the American and Native culture with English in our elementary schools helping young learners to acquire the language.

From now on I would like to share my experience while integrating the American culture during my English classes working with kids from 8 to 12 years old.

I will suggest some considerations on what to teach and how to teach culture through very easy techniques that young learners can find attractive, meaningful, and comprehensible.

But before presenting any content about American culture it is important to clarify to the students that there are many countries in which English is spoken but they are going to learn about a beautiful and interesting country called United States.

I have formulated a golden rule for English teachers willing to teach American culture and English to young learners which is to be very creative, patient and good searchers of the target culture.

Some steps that I would initially suggest for integrating the American culture and English into the elementary classroom are:

First, raise the students' curiosity and empathy toward the target culture and its people so students would be interested in learning the American culture. Try not to talk about the United States as it is a distant country.

Second, explain using common and simple situations some characteristics of American people.

Third, show them the differences in social roles such as age, sex, social class, residence variables that affect the 
way some Americans speak and behave. We need to allow students to relate the same issues to their own lives. As every English teacher knows, students love to talk about themselves.

Fourth, give the students simple instructions, the level of the students must be suitable to their abilities and skills, get to know your students before teaching culture themes. You are the only one who knows what culture details your students can achieve and understand.

Fifth, pick out the interesting aspects of the culture and present them in a way that will engage students. By using creative techniques, add other ingredients like passion and enthusiasm and you will get an exciting class for the students.

These steps should be followed in order to prepare them to receive new culture information and a different English class.

We can teach English through the teaching of American culture and our native culture but here comes an important question: What cultural themes and techniques are appropriate for young learners in public elementary schools?

One important consideration about this question is to keep in mind that any activity or technique designed to teach the target or native culture should challenge the students' perspectives on the target community and their cultural identity.

Teaching culture requires a variety of creative activities and techniques taking as a reference student's learning styles and their intelligences keeping in mind that there is no best way to teach anything. We have to use plenty of resources.

During the first weeks, teaching American culture and English to my students in Bernardo Gutiérrez Elementary School, I found out that choosing cultural themes is 
not an easy task; we have to be very careful when we decide what to teach to the students.

The content or information we are going to bring to the class must be very simple and short to provide comprehensible input.

This task can take a lot of thinking and we find ourselves wondering what should we focus on? How can we decide on the themes to teach?

The answer to this question would be to define the skills and themes that students need in order to increase their ability to communicate effectively in the target language according to their level of proficiency.

Here, I propose some simple culture themes that teachers can work with the students that would increase their cultural competence for instance: values, beliefs, traditions, religion, food, holidays, symbolism, order, ceremony, love, humor, beauty, the art of living, friendship, family, liberty, and education.

Some of the themes proposed above are being already introduced and studied with some of the groups I teach and I can say that I am getting good results due to the combination of some target themes with information about our native culture.

It is important to introduce native and target culture data providing students a context of the new information they are receiving, increasing their level of comprehension and motivating them to compare, learn, differ, and discover both cultures.

The techniques and activities are tools that can lead us to the successful integration of the American culture and English in public elementary schools.

The designed and adaptation of this techniques should assure culture information understanding as well as to promote spaces for values discussion (acceptance, respect, and 
appreciation) in which students can appreciate both cultures and reinforce their own.

The following techniques have been adapted to teach in an integral way the American and native culture with the teaching of English in public elementary schools taking as a reference the students' level of proficiency and skills.

\section{Cultural images}

To portray many aspects of the target culture posters, pictures, maps, signs, and realia are essential in helping students to develop a mental image of the topic introduced. Short presentations on a topic of interest with appropriate pictures or slides can provide more cultural input that students would understand. Introduce students to borrowed words in their native language; this helps students to realize they already know many words in the target language (ok, bye).Some food they eat is another example of the influence of the foreign culture (hamburgers, hotdogs).This activity can be used with students from second to sixth grades.

\section{Culture clips}

A Culture clip consists of a brief description of some aspects of the target language culture through magazine pictures, photos or realia. For example, introduce activities accustomed for holidays. Here we can include a comparison between what Americans do and our activities during similar holidays. This activity can be done with students from third to sixth grades.

\section{Mini-Dramas}

Mini-dramas consist on performing brief episodes in which misunderstandings are portrayed. The idea is to raise the students' empathy for the target culture and identify 
problems in communication. We have to be careful while choosing the situations they should be very simple and short.

Appropriate for fifth and sixth grades.

\section{Hear and act out}

This technique consists of verbal instructions given to the students in which they act out or carry out the instruction. This is excellent for any cultural routine that requires physical actions (eating, shaking hands, listening actively, standing in line to buy a ticket, etc.)

The students can get in two groups one performing the instructions in an American way and the other group in a Costa Rican style.

All levels can enjoy this technique.

\section{Media}

Videos can be used to teach culture. The teacher presents a video with an explanation of the situation and what it means in terms of the target culture. Many aspects of culture, such as appropriate dress for activities, kinds of activities students participate in on the weekend, public transportation, hobbies, school time can be effectively presented using media resources.

Good technique for fourth to sixth grades.

\section{Celebrating holidays}

Celebrating foreign and native holidays could be a fun activity for the students. Some examples are: bringing recipes from home, preparing for the holiday by drawing posters, decorating the room, and preparing food. Students can represent differences in the way both cultures celebrate holidays.

All levels can have fun through this technique. 


\section{Body movements}

Culture is a network of verbal and non-verbal communication. If our goal as foreign language teachers is to teach communication, we must not ignore the influence of non-verbal communication gestures. Gesture represents the feeling of the language it gives authenticity and makes language study more interesting. The idea is to encourage the students to use gestures when presenting dialogues, conversations or descriptions.

As teachers we know that the ways to be successful in teaching any subject is by showing students attractive and meaningful material. When it comes to teach students at the elementary classroom we should be aware that they need simple things and very colorful material.

These techniques encourage group work, discussions, interaction, and communication essential elements during the acquisition of a foreign language. If we apply the techniques and follow the suggestions presented so far, English teachers will discover by themselves along the process how easy it can be to teach American and native culture with the teaching of English. This can be a challenge for some English teachers and an elaborated work that takes time mainly to prepare material, search for data, and create or adapt the techniques but I believe we English teachers can make it real.

Teaching a foreign culture at the elementary classroom requires a lot from the teacher but if we want to change the routine and the class environment this integration results perfect and it would be a great gift for many students.

Finally, I would really like to motivate English teachers to try it, my first findings while integrating the teaching of the American culture and English are very surprising because my students were happy with this integration. 
They seem to enjoy and discover new things; they interact and participate as much as they can as they never did before during my English classes.

We need to give our language students more than just vocabulary, structures as it usually happens in most public elementary schools around the country. It is time to move on using the target language as a mean to teach culture.

In that way we will certainly lead the student to the development of communicative competence and cultural knowledge.

The teaching of at least one culture in which English is spoken needs to be integrated in the curriculum of the foreign language teaching in public elementary schools in our country. Teachers do indeed need to teach students a few critical skills that can help them develop and improve the quality of their communicative skills long their cultural knowledge that can help them «get their feet wet in the waters of another culture.»

There is no question teaching at least the American culture and our own along with English can contribute significantly to the acquisition of a foreign language.

There are many benefits and contributions we can get to improve the teaching of English in elementary schools not only their communicative competence and proficiency but cultural competence developing knowledge, sensitivity and empathy toward other cultures.

From all the above, it is evident that, we English teachers should not see the teaching of English as we used to. We should give our students the gift of enjoying the study of English and why not give ourselves the opportunity to re-direct and explore on more meaningful paths that motivate students toward the acquisition of English.

English teachers can show language learners that English can be more fun and really interesting because the 
ones in charge are not just teachers but magicians opening doors for them to discover new and wonderful worlds through English.

I really recommend elementary English teachers to give it a try! 